\title{
VALUE CREATION THROUGH SPIN-OFFS: A REVIEW OF THE EMPIRICAL EVIDENCE
}

By

\author{
Chris Veld ${ }^{1}$ and Yulia V. Veld-Merkoulova ${ }^{2,3}$
}

May 7, 2008

\begin{abstract}
:
This paper reviews the literature on the factors that influence the wealth effects associated with the announcements of corporate spin-offs (also known as demergers). We use metaanalysis to summarize the findings of 26 event studies on spin-off announcements. We find a significantly positive average abnormal return of 3.02\% during the event window. Returns are higher for larger spin-offs, for divestments that are tax or regulatory friendly and for spin-offs that lead to an improvement of industrial focus. We also find that spin-offs that are later completed are associated with lower abnormal returns than non-completed spin-offs. In the second part of the paper we overview studies on the long-run stock price performance of spinoffs. Even though early studies find a long-run superior performance, this effect is no longer found in later studies that use more refined statistical tests.
\end{abstract}

Keywords: spin-offs; demergers; value creation; event study; meta-analysis; long-run excess returns; industrial focus

JEL-classification: G32; G34

\footnotetext{
${ }^{1}$ Corresponding author. University of Stirling, Department of Accounting and Finance, Stirling, FK9 4LA United Kingdom (Scotland); Telephone: +441786467309; Fax: +441786467308; e-mail: c.h.veld@stir.ac.uk

${ }^{2}$ University of Stirling, Department of Accounting and Finance; e-mail: j.w.veld-merkoulova@stir.ac.uk

${ }^{3}$ The authors thank Frans de Roon, Ton Vorst, and Mike Wright for helpful comments and suggestions. Special thanks go to two anonymous referees and to the editor (Noel O'Sullivan) for their helpful comments and suggestions. The usual disclaimer applies.
} 


\title{
VALUE CREATION THROUGH SPIN-OFFS: A REVIEW OF THE EMPIRICAL EVIDENCE
}

\begin{abstract}
:
This paper reviews the literature on the factors that influence the wealth effects associated with the announcements of corporate spin-offs. We use meta-analysis to summarize the findings of 26 event studies on spin-off announcements. We find a significantly positive average abnormal return of 3.02\% during the event window. Returns are higher for larger spin-offs, for divestments that are tax or regulatory friendly and for spin-offs that lead to the divestiture of a non-related division. We also find that spin-offs that are later completed are associated with lower abnormal returns than non-completed spin-offs. In the second part of the paper we overview studies on the long-run stock price performance of spin-offs. Even though early studies find a long-run superior performance, this effect is no longer found in later studies that use more refined statistical tests.
\end{abstract}

Keywords: spin-offs; demergers; value creation; event study; meta-analysis; long-run excess returns; industrial focus

JEL-classification: G32; G34 


\section{Introduction}

In the last decades we have seen a large number of companies that reduced their size by spinning off one or more divisions. In a spin-off the shares of a firm's subsidiary are distributed pro-rata amongst the shareholders of the company. ${ }^{4}$ No cash transaction takes place. After the spin-off, the shareholders of the parent company hold shares in both the parent company and the subsidiary. ${ }^{5}$ In general, spin-offs are applauded by shareholders. For example, in February 2001 Canadian Pacific announced that it was going to spin off four of its subsidiaries, including Canadian Pacific Railway and PanCanadian Petroleum. After the spin-off Canadian Pacific's only significant business would consist of Canadian Pacific Hotels. On the day of the spin-off announcement, shares of Canadian Pacific went up \$5.60 to $\$ 57.15$, resulting in a return of almost 11 per cent on one day. In this paper we review the world-wide empirical evidence on the announcement date and long-run performance effects of spin-offs.

The popularity of spin-offs as a divestiture instrument varies widely across different countries. A possible reason for that lies in regulatory and fiscal restrictions. In the United States, spinoffs usually do not have tax consequences. Besides that, there are also no other legal barriers for spin-offs. In some European countries, regulation and taxation may cause barriers for spinoffs. ${ }^{6}$ For example, until February 1998, spin-offs were legally possible in the Netherlands. However, companies had to go through a long range of complicated procedures. Besides that, before June 1998, spin-offs in the Netherlands were seen as a distribution of income or capital and they were taxed accordingly. Under pressure from several large Dutch companies these rules were relaxed in 1998. From February 1998, legal barriers were reduced, creating a much simpler legal way to carry out spin-offs. From June 1998 spin-offs were also no longer taxed. Instead the fiscal claims were passed on to the future. This opened the way for one of the largest European spin-offs in which the Dutch telecom company KPN spinned off its postal

\footnotetext{
${ }^{4}$ Spin-offs are sometimes also referred to as demergers.

${ }^{5}$ There are also several other ways to reduce the size of the company. These include split-ups, split-offs, and carve-outs. In a split-up the shares of all the subsidiaries that comprise the firm are distributed. In this form of divestiture, the parent ceases to exist. This is also the case in a split-off. In this transaction, the parent's shareholders have to exchange the shares of the parent to obtain the shares in the subsidiaries. In an equity carveout, (some of) the shares of the subsidiary are sold to the public. Therefore, this type of divestiture involves a cash transaction. In this paper we will restrict ourselves to spin-offs.

${ }^{6}$ See Appendix A of Veld and Veld-Merkoulova (2006) for a detailed overview of taxation and regulation of European spin-offs.
} 
division TNT Post Groep. ${ }^{7}$ Gibbs (1999) states that spin-offs are still taxed unfavorably in France, Germany and Switzerland. This probably explains the low occurrence of spin-offs in France, where in the period from January 1987 to September 2000 a mere total of 7 spin-offs were announced. However, in other European countries spin-offs are more popular. For example, for the period from 1987 to 2000, Veld and Veld-Merkoulova (2004) document no less than 102 spin-offs announced in the United Kingdom.

In this paper we start by reviewing the empirical studies that have investigated the wealth effects associated with spin-offs. This review is in the form of a meta-analysis that is based on the methodology of Datta, Pinches, and Narayanan (1992), who do a meta-analysis on wealth effects associated with announcements of mergers and acquisitions. In the second part of the paper we study the literature on the long-run stock market performance of companies that are involved in a spin-off.

We find 26 papers that present event study results for spin-off announcements. Given that a large number of these studies present separate subsamples for specific variables, we have a total of 69 observations. The mean abnormal return for the 69 observations is $3.02 \%$. This number is significantly different from zero at the 1\%-level. Returns are higher for larger spinoffs. In addition we find that taxable spin-offs are associated with lower abnormal returns. Spin-offs that create tax or regulatory advantages give higher abnormal returns. We also find that spin-offs of unrelated divisions are associated with higher abnormal returns. An unexpected result from the meta-analysis is that spin-offs that are later completed show lower abnormal returns than spin-offs that are later withdrawn. This topic requires some additional research.

The factors mentioned in the academic literature are close to those mentioned by practitioners. For example, with regard to the earlier mentioned spin-offs by Canadian Pacific, the Chief Executive Officer of this company, David O’Brien, states:

This reorganization is the right step to take for our shareholders, for these five exceptional companies, and for the wider investment community. It will reward our shareholders now, by unlocking the full value of each business, and in the future, by providing them an excellent opportunity to participate in future growth and development of the business and their industries. It will better equip each business to pursue even greater success by providing them with direct access to public equity markets and shares that can be used as acquisition currency and incentive compensation. It will also allow the management of each company to

\footnotetext{
${ }^{7}$ The market value of KPN and TNT Post Groep after the spin-off were respectively US \$17.9 billion and US $\$ 11.6$ billion, making it one of the largest spin-offs in Europe.
} 
evaluate its growth opportunities and organize its capital structure according to its own industry. As well, the investment community will be able to more easily follow and accurately value these industry leaders on a stand-alone basis against competitors, benchmarks and performance criteria specific to each business sector. ${ }^{8}$

In this press release, David O’Brien clearly indicates the improvement of industrial focus as one of the reasons for the CP-spin-off. In a questionnaire study, Mukherjee, Kiymaz, and Baker (2004) investigate motives for divestitures. They find that the increase of focus is the most important reason for $36 \%$ of the managers in their study. ${ }^{9}$

We also review the papers that study the long-run performance of spun off divisions and their parent companies. Early papers find some evidence for a superior long-run performance after the announcement period. However, the techniques used in these early papers are criticized in the academic literature (see e.g. Fama (1998)). Later studies that use a more refined methodology find that there is no evidence of a superior performance of spin-offs after the announcement period.

The remainder of this paper is organized as follows. Section 2 briefly reviews the studies on the wealth effects of the spin-offs. Factors that can potentially explain the wealth effects of spin-offs are discussed in Section 3. Section 4 includes the model for the meta-analysis as well as the results of this analysis. Section 5 analyzes the studies on the long-run performance of spin-offs. The paper concludes with Section 6 which summarizes the results of these studies and discusses possible topics for future research.

\section{Wealth effects of spin-offs}

A large number of studies analyze the stock returns that are associated with spin-offs. The reason for this is that the shareholders are the most important party in this transaction. All these event studies document abnormal returns associated with the spin-off announcement. An important problem in analyzing these studies is that most of them use different criteria for including spin-offs. For example, some studies only include spin-offs that were eventually completed. Other studies also include spin-off announcements that were later withdrawn. In

\footnotetext{
${ }^{8}$ Source: The press release of Canadian Pacific on February 13, 2001 entitled: "Canadian Pacific to enhance shareholder value by spinning off its businesses". See http://www.cpships.com/newsarchivedt.asp?NewsID=156 for the entire press release.

${ }^{9}$ It should be mentioned that most of the divestitures, which the managers in their sample were involved in, consisted of outright sales of units to other firms, rather than spin-offs.
} 
addition, many studies try to find out which factors explain the wealth effects of spin-offs, with different variables used as factors. In order to review and draw conclusions from all these studies we use a meta-analysis technique. We follow the approach of Datta, Pinches, and Narayanan (1992) who use a meta-analysis to study the wealth effects associated with the announcement of mergers and acquisitions. In our meta-analysis the estimates of abnormal returns associated with spin-offs from previous empirical studies are used as observations in a multi-factor experiment, with the experimental factors corresponding to the factors hypothesized to influence wealth creation. Therefore the abnormal returns are the dependent variable. We use a multivariate regression analysis to assess the impact of each factor on the dependent variable.

As a starting point for the meta-analysis we use library catalogues and the internet (Google) to select all studies that present event study results for spin-off announcements. These studies include papers in academic journals, working papers, and papers in books. This search results in 26 studies, of which 21 were published (or are forthcoming in) academic journals, 4 working papers, and 1 paper published in a book. The papers were published between 1983 and 2008. We only include papers that present separate results for spin-offs. ${ }^{10}$ Given that spinoffs are quite common in the United States, most studies are on that country. However, in recent years studies appeared also on Western Europe and on Malaysia. Table 1 summarizes the 26 papers and the wealth effects that they report.

[Please insert Table 1 here]

From this table it directly becomes clear that spin-offs are associated with positive abnormal returns. The magnitude of these returns is different over individual studies, since they generally use different datasets and different methodologies. However, the main conclusion is consistent: spin-offs are associated with strongly significant abnormal returns that range from $1.32 \%$ to $5.56 \%$. The only exception is the study of Murray (2000) for the United Kingdom, which reports a non-significant abnormal return of $-0.19 \%$ for the event window from day -1 to day 1. However, the study of Schauten, Steenbeek, and Wycisk (2001) for the same country and for the same event window shows an abnormal return of $2.13 \%$. The studies of Veld and

\footnotetext{
${ }^{10}$ The studies of Koh, Koh, and Koh (2005) for Singapore and Coakley, Thomas, and Wang (2008) for the United Kingdom for example were excluded because they only present results for several types of divestitures (spin-offs, carve-outs, and sell-offs) together. The study of Abarbanell, Bushee, and Raedy (2003) was excluded because they only report abnormal returns around the date that the spin-off becomes effective.
} 
Veld-Merkoulova (2004) and Sudarsanam and Qian (2007) present separate subsamples for the United Kingdom. Both studies find significantly positive abnormal returns for the same event window of respectively $2.54 \%$ and $2.79 \%$. Therefore it is reasonable to conclude that in all the areas that are studied (United States, Western Europe, United Kingdom, and Malaysia) spin-offs are associated with significantly positive abnormal returns.

\section{Factors explaining wealth effects of spin-offs}

This section presents factors that can possibly explain the wealth effects of spin-offs. For each factor we select one or two variables for the meta-analysis.

\subsection{Improvement of industrial focus}

Starting with Berger and Ofek (1995), extensive research has shown that the equity of diversified firms is traded at a discount compared to single business firms. A spin-off is a relatively simple way to improve the focus of the firm and to avoid the diversification discount. Therefore, a spin-off allows the firm to concentrate on its core business. This idea is also confirmed in statements by financial analysts. For example, in an article in USA Today Peter McKelvey, partner at L.E.K. Consulting says: "Investors have clearly shown unrelated businesses are better off separated (..) What sounds theoretically interesting together...doesn't live up to the hype". 11

There are two different ways in which event studies investigate the effect of an improvement of industrial focus. Some studies take the stated objective from the spin-off announcement as a starting point. They present abnormal returns for subsamples for which management states that the spin-off will be carried out in order to specialize or to go "back to basics" (Hite and Owers, 1983, and Johnson, Klein, and Thibodeaux, 1996). Other studies, starting with Daley, Mehrotra, and Sivakumar (1997), define focus-increasing spin-offs as spin-offs in which the parent company is in a different industry from the subsidiary or use other measures of focus, such as the reduction in the Herfindahl index or the number of segments reported by the firm (Desai and Jain, 1999).

\footnotetext{
${ }^{11}$ See: "Many spin-offs prove popular with investors”, USA Today, June 16, 2005, available at: http://www.usatoday.com/money/markets/us/2005-06-15-spinoffs-usat_x.htm
} 
We use proxies for both ex ante and ex post distinctions in our meta-analysis. The back-tobasics variable is used for subsamples that are based on the statements of management that they announce a spin-off in order to specialize or go back-to-basics. The industrial focus variable is used for studies or subsamples that only include spin-offs where the parent company is in a different industry from the subsidiary.

\subsection{Information asymmetry}

Habib, Johnsen, and Naik (1997) present an information-based explanation for spin-offs. They derive a model in which a firm can increase its value by spinning off a subsidiary. The spin-off will lead to an increase of the number of securities that is traded on the market. This makes the price system more informative and, hence, leads to a decrease of information asymmetry. This decrease of information asymmetry will lead to an increase of the total value of the firm and its spun off subsidiaries.

Krishnaswami and Subramaniam (1999) are the first to test whether firms may engage in a spin-off because there is information asymmetry between the management of the firm and the external capital market. Like Habib, Johnsen, and Naik (1997), they argue that it is likely that after the spin-off information asymmetry, and hence undervaluation, will decrease. Krishnaswami and Subramaniam (1999) use a number of different measures of information asymmetry; three of these measures are based on data from the Institute of Brokerage for Investment Services (IBES) on analysts forecast errors; the remaining two measures are based on the volatility around earnings announcements. Following Krishnaswami and Subramaniam (1999), Veld and Veld-Merkoulova (2004) also report results for separate subsamples based on similar measures of information asymmetry. We include information asymmetry as a variable in the meta-analysis.

\subsection{Tax treatment}

In general spin-offs by American companies do not have tax consequences. However, there are some exceptions. Schipper and Smith (1983) and Copeland, Lemgruber, and Mayers (1987) argue that in some cases the tax status of a firm can be improved by spinning off specific assets. Examples include the formation and spin-off of real estate natural resource 
royalty trusts or oil royalty trusts. These trusts do not pay income taxes and they pay $90 \%$ of their income as dividends to shareholders. Another example that Schipper and Smith (1983) mention is Real Estate Investment Trusts (REITs). However, Goolsbee and Maydew (2002) state that until 2001 it was not sure whether spin-offs of REITs would be taxed. They argue that because of uncertainty no firm was willing to take the risk of undertaking a REIT spinoff. In 2001 the IRS issued a ruling allowing firms to engage in nontaxable REIT spin-offs. This was immediately following by a large REIT spin-off of timber properties by GeorgiaPacific. ${ }^{12}$ Goolsbee and Maydew (2002) speculate that the IRS ruling would potentially lead to a large number of REIT spin-offs with an estimated net tax revenue decrease of $\$ 823$ million per year.

In some cases American spin-offs can have negative tax consequences. Copeland, Lemgruber, and Mayers (1987) state that, generally speaking, spin-offs are non-taxable for shareholders if the spun off entity was (at least 50 percent) controlled by the parent corporation. However, if the spin-off is a minority interest it is taxed at the capital gains rate. There is also a possibility of partial taxation.

The tax situation in Europe is largely derived from the so-called "Merger Directive" that was adopted by the European Union on July 23, 1990. According to this directive, the capital gains taxation on a spin-off is deferred. In other words, the tax authorities consider a spin-off as the re-arrangement of investments that the investor already owns, and as a result, levy no taxes. This directive applies to intra-community spin-offs. The ultimate intention for this directive is its application in all countries within the European Union. ${ }^{13}$ According to Gibbs (1999) tax deferral in spin-offs already occurs in Belgium, Italy, the Netherlands (from 1998), Sweden, and the United Kingdom. He also states that there are several European countries where tax authorities see a spin-off as a distribution of income or capital and tax it accordingly. This rule applies to France, Germany and Switzerland. In Germany, spin-offs can be arranged in a tax-neutral way. However, if more than $20 \%$ of the shareholders transfer their shares within 5 years after the spin-off, the spin-off will still be taxed (Zaman (1998)). In France, the problem is that it is not possible for the company to ask for approval from the tax authorities before the transaction is carried out. In both Germany and France, it is not known at the announcement date whether the spin-off will be taxed. The decision on the taxation in

\footnotetext{
12 The spun-off REIT merged with an existing REIT and joined the S\&P 500 as Plum Creek Timber Company.

${ }^{13}$ See Raedler (1994).
} 
France will only be taken after the spin-off date. In Germany it will depend on the transfer of shares in the period after the spin-off.

Our meta-analysis includes proxies for both tax advantages and taxable spin-offs. These variables are based on studies that restrict themselves to spin-offs that are carried out because of tax advantages or that separately report subsamples of spin-offs that are carried out for this reason (Schipper and Smith, 1983, Copeland, Lemgruber, and Mayers, 1987, Desai and Jain, 1999, and Michaely and Shaw, 1995) or that report (sub)samples for either taxable or nontaxable spin-offs (Desai and Jain, 1999, and Krishnaswami and Subramaniam, 1999).

\subsection{Regulatory motives}

Schipper and Smith (1983) argue that regulation may be a motive for American firms to engage in a spin-off. They mention two separate cases in which this may apply. The first possibility is if a parent spins off a rate-regulated utility. In this case the spun off utility can no longer be subsidized by cash flows from unregulated operations. According to Schipper and Smith (1983) a loss in subsidy may lead to an increase in the speed and/or magnitude of rate increases. The second possibility that they mention is where a multinational firm spins off a foreign subsidiary in order to exempt the latter from restrictions imposed by Congress on domestic firms operating abroad. Such regulatory advantages do not seem to exist outside the United States.

We include a variable for regulatory advantages in the meta-analysis. This variable is based on studies that either restrict themselves to spin-offs that are carried out in order to profit from regulatory advantages or that report separate subsamples for such spin-offs (Schipper and Smith, 1983, and Krishnaswami and Subramaniam, 1999).

\subsection{Spin-off size}

A number of studies find that the wealth effects are larger when the portion of assets that is divested is larger. This result is in line with intuition, since the impact of spinning off a large division can be expected to be bigger than the spin-off of a relatively small division. We test for this effect by including a variable for size in the meta-analysis. 


\subsection{Completed spin-offs}

A large number of empirical studies restrict themselves to announcements of spin-offs that were later completed. Other studies present separate subsamples for completed and noncompleted spin-offs (see Copeland, Lemgruber, and Mayers, 1987, and Kirchmaier, 2003). For this reason we also include a variable for completed spin-offs.

\subsection{United States versus other countries}

Most of the original research on spin-offs is carried out for the United States. It is interesting to see whether the results of other countries corroborate the American results. In this sense the studies of countries outside the United States can be considered as an out-of-sample test for the question whether spin-off announcements are associated with positive abnormal returns. For this reason we include a variable for United States spin-offs.

\subsection{Early study}

We also want to study whether the results of spin-off announcements have changed throughout the years. We study this by including a separate variable for early studies. Early studies are defined as studies that were published in 1997 or earlier, with half of our sample classified as early studies.

\subsection{Publication bias}

It is possible that event studies that report significantly positive or negative abnormal returns get easier published in refereed journals than event studies that find non-significant abnormal returns. For instance, Card and Krueger (1995) find evidence of publication bias in studies on the relation between minimum wage and unemployment. We include two variables for a possible publication bias. The first variable, Top-3 journal, measures whether the study was published in one of the Top-3 finance journals, i.e. The Journal of Finance, Journal of 
Financial Economics or The Review of Financial Studies. The second variable, SSCI, measures whether the study was published in one of the journals included in the Social Sciences Citations Index (SSCI). For this purpose we used the list of journals of 2006.

\section{Meta-analysis}

\subsection{Model}

To assess the impact of the factors described in Section 3 on the wealth effects of the spin-off announcements, we employ a meta-analytic procedure to estimate the significance of the hypothesized independent variables on abnormal spin-off announcement date returns. For this purpose we follow a replication analysis methodology used by Datta, Pinches, and Narayanan (1992) who study merger returns for bidders and targets. The estimates of spin-off announcement date abnormal returns from previous empirical studies play the role of observations in a multi-factor natural experiment, with the experimental factors corresponding to the factors hypothesized to influence wealth creation. The following multiple regression approach is employed using the earlier described dummy variables as factors and abnormal returns as dependent variables:

$\mathrm{AR}_{\mathrm{t}}=f$ (Back-to-basics, industrial focus, information asymmetry, tax advantages, taxable spin-offs, regulatory advantages, size, completed, United States, early study, Top-3 journal, SSCI)

Where:

$\mathrm{AR}_{\mathrm{t}}$

Back-to-basics

Industrial focus

Information asymmetry
$=$ Abnormal return for event period $\mathrm{t}$

= Management statement that spin-off is announced in order to specialize or go "back-to-basics" (1 = Statement is made)

= Parent company is in a different industry from the subsidiary (1 = Yes)

= Measure of information asymmetry between management of the firm and outsiders ( 1 = High information asymmetry) 
Tax advantages

Taxable spin-offs

Regulatory advantages

Size

Completed

United States

Early study

Top-3 journal

SSCI
= Spin-off leads to a tax advantage $(1=$ Yes $)$

= Spin-off is taxable $(1=$ Yes $)$

= Spin-off leads to a regulatory advantage $(1=$ Yes $)$

$=$ Relative size of spin-off compared to total assets of the parent firm (1 = Large)

= Spin-off is completed after the announcement $(1=$ Yes $)$

= Study is on American spin-offs (1 = USA spin-off)

$=$ Year in which study is either published, or the latest draft of the working paper ( 1 = published in 1997 or earlier)

$=$ Published in one of the Top-3 finance journals, i.e. The Journal of Finance, Journal of Financial Economics or The Review of Financial Studies (1 = Yes)

$=$ Published in a journal that is included in the list of the Social Sciences Citations Index (SSCI) of 2006 (1 = Yes)

This procedure allows us to test the impact of each independent variable after controlling for the effects of the other variables. The regression intercept is the main effect and each dummy variable adds or subtracts from the main effect.

\subsection{Results of the meta-analysis}

The basis for our meta-analysis consists of the 26 studies summarized in Table 1 . This sample was constructed by searching library catalogues, electronic databases, Social Sciences Research Network (SSRN), and the internet (Google and Google Scholar) for studies that present event study results for spin-off announcements. In the context of this search we also contacted some researchers to ask for their unpublished papers, which they kindly sent to us. We are confident that the final data-set of 26 papers comprises the entire available data-set on papers that study spin-off announcements.

Where available we select the event interval from day -1 to day 1 . For studies where this interval is not available we use the closest possible alternative. For all studies, except Denning (1988) this is the interval from day -1 to day 0. For the Denning study we use the interval from day day -6 to day 6 . Since a large number of the 26 studies present separate subsamples 
for at least one of the variables mentioned in Section 3 we have a total of 69 observations. Table 2 includes the mean and median abnormal returns for spin-off announcements with cross-sectional $t$-statistics and Wilcoxon tests.

[Please Insert Table 2 here]

The mean abnormal return for the 69 observations is 3.02\%. This number is significantly different from zero on the $1 \%$-level. The median is $2.90 \%$ and is also significantly different from zero at the $1 \%$-level. The minimum abnormal return is $-5.29 \%$ and the maximum abnormal return is $7.80 \%$. The results from the regressions are included in Table 3.

[Please insert Table 3 here]

The first model in Table 3 shows that the back-to-basics variable is not significant. Apparently, the fact that the company reports itself that it plans to spin-off a segment in order to specialize, or go back-to-basics, does not significantly affect abnormal returns. However, the coefficient of the industrial focus variable is significant on the $1 \%$-level. This means that the stock market is more positive about a proven going-back-to-basics activity, rather than to just rely on what the company reports. The coefficient of 1.34 means that industrial-focus increasing spin-offs result in $1.34 \%$ higher abnormal returns. The variable for information asymmetry is not significant, which casts doubt on this being a motive in practice for carrying out a spin-off. Tax advantages and regulatory advantages are both associated with higher abnormal returns. Also, the other side of the tax question, taxable spin-offs, shows a significantly negative sign (on the 10\%-level). Size shows the expected significantly positive sign (on the 1\%-level). A remarkable result is that completed spin-offs gives a significantly negative coefficient (on the 10\%-level). Apparently the stock market reacts more positively to spin-offs that were ex post not completed. A possible reason for this is that these spin-offs were less expected than spin-offs that were later completed and that their announcement had a higher information content. Future research should reveal why this is the case. The variable for early study is not significant. The variable for United States is also not significant, indicating that spin-off wealth effects are not country specific.

In the second model we include the same variables, but we add the first variable for publication bias, Top-3 journal. This variable is not significant. Adding this variable does not change the significance level of the other proxies, except that taxable spin-offs and regulatory advantages are no longer significant. In the third model we replace Top-3 journal by the 
second variable for publication bias, SSCI. This variable is also not significant. This suggests that the studies we review do not suffer from a publication bias, that is, higher abnormal returns found in a study do not increase its chances of being published in a journal that is included in the SSCI-index. In this model, taxable spin-offs is significantly negative at the $10 \%$-level and regulatory advantages is significant at the 5\%-level. In addition, the significance of the completed variable disappears.

Finally we run a regression with all the variables that showed a significant sign in at least one of the first three models: industrial focus, regulatory advantages, tax advantages, taxable spin-offs, size, and completed. The results of this regression are included in the fourth model in Table 3. This regression shows significant signs for all included variables. Apparently these are the variables that show the strongest effect. The explanatory power of the regressions is fairly high. The $\mathrm{R}^{2}$ of the three regressions varies between 0.24 and 0.26 and the adjusted $\mathrm{R}^{2}$ varies between 0.12 and $0.17 .^{14}$

\section{The long-run performance of companies involved in spin-offs}

The results of the meta-analysis presented in Section 4 show that spin-offs are unambiguously associated with positive abnormal returns on the announcement day. On average, announcing a spin-off increases the value of company equity by about 3\%. In only 2 subsamples out of 69 negative abnormal returns were reported. A related research question that a few studies try to answer is whether the wealth effects of spin-offs are limited to the announcement returns, or do they persist in the longer-run, after the spin-off is completed. These studies are summarized in Table 4.

\section{[Please insert Table 4 here]}

The first paper on this topic is by Cusatis, Miles, and Woolridge (1993). They study the stock price performance of U.S. firms after a spin-off. This stock price performance is calculated using Buy-and-Hold Abnormal Returns (BHARs). These returns are corrected for returns on matching firms. Their paper includes results for parents, subsidiaries, and pro-forma

\footnotetext{
${ }^{14}$ Given that the study of Denning (1988) uses a different event interval from the other studies (day -6 to +6 instead of day -1 to +1 or day -1 to 0 ), we have also ran all the regressions without the Denning (1988) study. The only result that changes is that the taxable variable in Regression (1) is no longer significant: the $t$-statistic for this coefficient changes from -1.70 to -1.64 . For the remainder the results remain unchanged. These results are available from the authors on request.
} 
combined firms. The latter are created by weighing the return of the parent company, and that of the subsidiary, by the market value of the firm on the spin-off date. As can be seen from Panel A of Table 4, Cusatis, Miles, and Woolridge (1993) find a significant long-run abnormal performance in the period of 2 years after the spin-off date. Panels B and C show that this performance is driven by both the parents and the subsidiaries. Their paper has had a large impact in the financial industry. After the publication of this paper, the popular press picked up the idea that a strategy of buying parents and subsidiaries involved in spin-offs would lead to a superior portfolio performance. There were also reports in the press that managers started to implement such strategies in particular investment funds. ${ }^{15}$

Fama (1998) criticizes the use of BHARs by Cusatis, Miles, and Woolridge (1993) and other authors on different topics. With regard to the Cusatis, Miles, and Woolridge (1993) paper he writes (page 303): “The t-statistics for the three-year BHARs for spinoffs range from 0.58 to 2.55, hardly overwhelming. Moreover, in calculating the t-statistics, the BHARs of the event firms are assumed to be independent. It would not take a large adjustment for crosscorrelation to produce t-statistics that suggest no real anomaly". More recent papers on longrun performance use improved methodologies, such as the one derived by Lyon, Barber, and Tsai (1999). They present a method to adjust $t$-statistics for overlapping samples.

Desai and Jain (1999) also use the matching firm approach to calculate BHARs. They find significantly positive abnormal returns for the 3-year period following the spin-offs (see Panel A of Table 4). This result is especially driven by the highly significant returns of the subsidiaries. In addition, they find that the returns are much better for focus-increasing companies. The abnormal returns for the focus-increasing companies are significant $11.12 \%$, $20.77 \%$ and $33.36 \%$ over respective holding periods of one, two or three years following the spin-offs. This contrasts to non-significant abnormal returns of $-0.96 \%,-7.66 \%$ and $-14.34 \%$ in the same respective periods for the non-focus-increasing spin-offs. However, Desai and Jain (1999) do not correct $t$-statistics for cross-correlation. It is not clear whether such adjustment would still have led to significant abnormal returns. ${ }^{16}$

McConnell, Ozbilgin, and Wahal (2001) and Veld and Veld-Merkoulova (2004) also use the matching firm approach, but they apply the methodology suggested by Lyon, Barber, and Tsai (1999) in order to calculate $t$-statistics. The study of Veld and Veld-Merkoulova (2004) does

\footnotetext{
${ }^{15}$ See McConnell, Ozbilgin, and Wahal (2001) for references.

${ }^{16}$ The $t$-statistic that they report is only 2.17 .
} 
not find any significant abnormal returns for European companies. A similar result for Europe is found by Sudarsanam and Qian (2007). The study of McConnell, Ozbilgin, and Wahal (2001) for U.S. firms also shows non-significant returns. In addition they argue that, even though their returns are positive, they are largely driven by one large outlier. They conclude their paper by stating (page 278): "Overall, from our perspective, the results of our analysis indicate that post-spin-off stock returns do not provide robust evidence against the semistrong form of the efficient market hypothesis".

\section{Conclusions and topics for future research}

In this paper we have reviewed the existing empirical evidence on value creation through spin-offs. A meta-analysis using the 26 studies that report wealth effects associated with spinoff announcements shows a significantly positive average abnormal return of 3.02\% during the event window. An important result is that spin-offs that lead to an improvement of industrial focus are associated with larger abnormal returns. This result confirms the idea that dispositions involving assets outside the core business of a firm are viewed by the market as value-increasing whereas this does not apply to the disposition of core assets. Daley, Mehrotra, and Sivakumar (1997) argue that this confirms a general result on the positive relation between firm value and corporate focus (as documented by, e.g., Berger and Ofek, 1995). The result that larger spin-offs are associated with higher abnormal returns is possibly related to the industrial focus result. The divestiture of a large non-related subsidiary is likely to be received more favorable than the divestiture of a small non-related subsidiary.

In addition, we find that returns are higher for spin-offs that receive a tax or regulatory friendly treatment. A surprising result is that spin-offs that are later completed are associated with lower abnormal returns than those that were not completed. A possible reason for this result is that the spin-offs that were ex post not completed were less expected by the market participants. Future research should shed more light on this. A possible way to study this result is to carry out research around the announcements of spin-off withdrawals.

Another topic for future research is to acquire more evidence on spin-off announcements outside the United States. At this point, the amount of research outside this country is still fairly limited with only studies on the United Kingdom, Western Europe, and Malaysia being 
available. This is very modest, compared to for example the amount of research on initial public offerings outside the United States. A third topic for future research is the long run performance of spin-offs. It would be interesting to replicate the original study of Cusatis, Miles, and Woolridge (1993) using the refined methodology that was developed recently. This would give a more conclusive answer to the question whether spin-offs are associated with a superior long-run stock price performance. The final and probably most interesting topic for future research relates to the fact that there are still many large conglomerates that combine many unrelated divisions. Given that spin-off announcements are associated with high positive abnormal returns, especially for spin-offs of unrelated divisions, this raises the question why these conglomerates are still in one piece. It would be interesting to study why this potential for abnormal returns is not exploited. 


\section{References}

- $\quad$ Abarbanell, J.S., Bushee, B.J. and Raedy, J.S. (2003). Institutional investor preferences and price pressure: The case of corporate spin-offs. Journal of Business, 76, 233-261.

- $\quad$ Allen, W.A., Lummer, S.L., McConnell, J.J. and Reed, D.K. (1995). Can takeover gains explain spin-off gains? Journal of Financial and Quantitative Analysis, 30, 465-485.

- $\quad$ Ball, J.N., Rutherford, R.C. and Shaw, R.J. (1993). The wealth effects of real estate research spin-offs. The Journal of Real Estate Research, 8, 597-606.

- $\quad$ Berger, P.G. and Ofek, E. (1995). Diversification's effect on firm value. Journal of Financial Economics, 37, 39-65.

- Card, D., and Krueger, A.B. (1995). Time-series minimum-wage studies: A metaanalysis. The American Economic Review, 85, 238-243.

- Coakley, J., Thomas, H. and Wang, H.M. (2008). The short-run wealth effects of foreign divestitures by UK firms. Applied Financial Economics, 18, 173-184.

- $\quad$ Copeland, T.E., Lemgruber, E.F. and Mayers, D. (1987). Corporate spinoffs: multiple announcement and ex-date abnormal performance, In Copeland, T.E. (ed.), Modern Finance and Industrial Economics: Papers in honor of J. Fred Weston. Basil Blackwell Inc., 114-137.

- $\quad$ Cusatis, P.J., Miles, J.A. and Woolridge, J.R. (1993). Restructuring through spinoffs: the stock market evidence. Journal of Financial Economics, 33, 293-311.

- $\quad$ Daley, L., Mehrotra, V. and Sivakumar, R. (1997). Corporate focus and value creation: evidence from spinoffs. Journal of Financial Economics, 45, 257-281.

- $\quad$ Datta, D.K., Pinches, G.E. and Narayanan, V.K. (1992). Factors influencing wealth creation from mergers and acquisitions: a meta-analysis. Strategic Management Journal, 13, 67-84.

- $\quad$ Denning, K.R. (1988). Spin-offs and sales of assets, Accounting and Business Research, 19, 32-42.

- $\quad$ Desai, H. and Jain, P.C. (1999). Firm performance and focus: long-run stock market performance following spinoffs. Journal of Financial Economics, 54, 75-101.

- Fama, E.F. (1998). Market efficiency, long-term returns, and behavioral finance. Journal of Financial Economics, 49, 283-306.

- $\quad$ Gibbs, P. (1999). Quarterly focus: European spin-off market, Morgan Guaranty Trust Company, Mergers \& Acquisitions Research, London, April 23.

- $\quad$ Goolsbee, A. and Maydew, E. (2002). Taxes and organizational form: the case of REIT spin-offs. National Tax Journal, 55, 441-456.

- $\quad$ Habib, M.A., Johnsen, B.D. and Naik, N.Y. (1997). Spinoffs and information. Journal of Financial Intermediation, 6, 153-176.

- $\quad$ Hite, G.L. and Owers, J.E. (1983). Security price reactions around corporate spin-off announcements. Journal of Financial Economics, 12, 409-436. 
- Johnson, S.A., Klein, D.P. and Thibodeaux, V.L. (1996). The effects of spin-offs on corporate investment and performance. The Journal of Financial Research, 19, 293307.

- Kirchmaier, T. (2003). The performance of European demergers. Working paper, Centre for Economic Performance, London School of Economics, May.

- $\quad$ Koh, F., Koh, W.T.H. and Koh, B.S. (2005). Corporate divestitures and spinoffs in Singapore. Journal of Restructuring Finance, 2, 69-79.

- $\quad$ Krishnaswami, S. and Subramaniam, V. (1999). Information asymmetry, valuation, and the corporate spin-off decision. Journal of Financial Economics, 53, 73-112.

- $\quad$ Lyon, J.D., Barber, B.M. and Tsai, C.L. (1999). Improved methods for tests of long-run abnormal stock returns. The Journal of Finance, 54, 165-201.

- Maxwell, W.F. and Rao, R.P. (2003). Do spin-offs expropriate wealth from bondholders? The Journal of Finance, 58, 2087-2108.

- $\quad$ McConnell, J.J., Ozbilgin, M. and Wahal, S. (2001). Spin-offs, ex ante. Journal of Business, 74, 245-280.

- $\quad$ Michaely, R. and Shaw, W.H. (1995). The choice of going public: spin-offs vs. carveouts. Financial Management, 24, Autumn, 5-21.

- $\quad$ Miles, J.A. and Rosenfeld, J.D. (1983). The effect of voluntary spin-off announcements on shareholder wealth. The Journal of Finance, 38, 1597-1606.

- $\quad$ Mukherjee, T.K., Kiymaz, H. and Baker, H.K. (2004). Merger motives and target valuation: A survey of evidence from CFOs, Journal of Applied Finance, 14, Fall/Winter, 7-24.

- Mulherin, J.H. and Boone, A.L. (2000). Comparing acquisitions and divestitures, Journal of Corporate Finance, 6, 117-139.

- Murray, L. (2000). An assessment of the wealth effects of spin-offs on the London Stock Exchange. Working Paper, University College Dublin.

- $\quad$ Raedler, A.J. (1994). General report on the conference on national and international tax consequences of demergers, International Fiscal Association, Toronto.

- Rosenfeld, J.D. (1984). Additional evidence on the relation between divestiture announcements and shareholder wealth, The Journal of Finance, 39, 1437-1448.

- $\quad$ Schauten, M.B.J., Steenbeek, O.W., and Wycisk, E.M. (2001). Waardecreatie door spinoffs (transl. Value creation by means of spin-offs), Tijdschrift Financieel Management, 21, March/April, 69-77.

- $\quad$ Schipper, K. and Smith, A. (1983). Effects of recontracting on shareholder wealth: the case of voluntary spin-offs, Journal of Financial Economics, 12, 437-467.

- $\quad$ Seifert, B. and Rubin, B. (1989). Spin-offs and the listing phenomena, Journal of Economics and Business, 41, 1-19.

- $\quad$ Seward, J.K. and Walsh, J.P. (1996). The governance and control of voluntary corporate spin-offs, Strategic Management Journal, 17, 25-39. 
- $\quad$ Sin, Y.C., and Ariff, M. (2006). Corporate spin-offs and the determinants of stock price changes in Malaysia, Working paper, Monash University, February.

- $\quad$ Slovin, M.B., Sushka, M.E. and Ferraro, S.R. (1995). A comparison of the information conveyed by equity carve-outs, spin-offs and asset sell-offs, Journal of Financial Economics, 37, 89-104.

- $\quad$ Sudarsanam, P.S. and Qian, B. (2007). Catering theory of corporate spin-offs: empirical evidence for Europe, Working paper, Cranfield University, May.

- Veld, C. and Veld-Merkoulova, Y.V. (2004). Do spin-offs really create value? The European case, Journal of Banking and Finance, 28, 1111-1135.

- $\quad$ Veld, C. and Veld-Merkoulova, Y.V. (2006). The announcement effects and long-run stock market performance of corporate spin-offs: international evidence, In: Renneboog, L.D.R. (ed.), Advances in Corporate Finance and Asset Pricing, Elsevier Sciences, 105132.

- $\quad$ Veld, C. and Veld-Merkoulova, Y.V. (2008). An empirical analysis of the stockholderbondholder conflict in corporate spin-offs, Financial Management, 37, Spring, 103-124.

- $\quad$ Vijh, A.M. (1994). The spin-off and merger ex-date effects, The Journal of Finance, 49, 581-609.

- White, H. (1980). A heteroscedasticity-consistent covariance matrix estimator and a direct test for heteroscedasticity, Econometrica, 48, 817-838.

- $\quad$ Zaman, D.F.M.M. (1998). Splitsing: juridisch en fiscaal (transl. Split-up: legal and fiscal), Kluwer Juridische Uitgevers, Deventer (the Netherlands). 
Table 1: Studies of the wealth effects associated with spin-off announcements.

\begin{tabular}{|c|c|c|c|c|c|}
\hline Study & Country & Research period & Observations & Event window & $\begin{array}{c}\text { Cumulative average } \\
\text { abnormal return }\end{array}$ \\
\hline Schipper and Smith (1983) & United States & $1963-1981$ & 93 & $(-1,0)$ & $2.84 \%^{* * * *}$ \\
\hline Hite and Owers (1983) & United States & $1963-1981$ & 123 & $(-1,0)$ & $3.3 \%{ }^{* * *}$ \\
\hline Miles and Rosenfeld (1983) & United States & $1963-1980$ & 55 & $(0,1)$ & $3.34 \%^{* * *}$ \\
\hline Rosenfeld (1984) & United States & $1963-1981$ & 35 & $(-1,0)$ & $5.56 \%{ }^{* * *}$ \\
\hline Copeland, Lemgruber, and Mayers (1987) & United States & $1962-1982$ & 188 & $(-1,0)$ & $3.03 \%^{* * *}$ \\
\hline Denning (1988) & United States & $1970-1982$ & 42 & $(-6,6)$ & $2.58 \%^{\text {n..r. }}$ \\
\hline Seifert and Rubin (1989) & United States & $1968-1983$ & 51 & $(-1,0)$ & $3.26 \%{ }^{* * *}$ \\
\hline Ball, Rutherford, and Shaw (1993) & United States & $1968-1990$ & 39 & $(-1,0)$ & $2.55 \%^{\text {n...r. }}$ \\
\hline Vijh (1994) & United States & $1964-1990$ & 113 & $(-1,0)$ & $2.90 \%{ }^{* * *}$ \\
\hline Allen, Lummer, McConnell, and Reed (1995) & United States & $1962-1991$ & 94 & $(-1,0)$ & $2.15 \%^{* * *}$ \\
\hline Michaely and Shaw (1995) & United States & $1981-1988$ & 9 & $(-1,1)$ & $3.19 \%{ }^{\text {n.r.r. }}$ \\
\hline Slovin, Sushka, and Ferraro (1995) & United States & $1980-1991$ & 37 & $(0,1)$ & $1.32 \%{ }^{* *}$ \\
\hline Seward and Walsh (1996) & United States & $1972-1987$ & 78 & $(-1,0)$ & $2.6 \%{ }^{* * *}$ \\
\hline Johnson, Klein, and Thibodeaux (1996) & United States & $1975-1988$ & 104 & $(-1,0)$ & $3.96 \%{ }^{* * *}$ \\
\hline Daley, Mehrotra, and Sivakumar (1997) & United States & $1975-1991$ & 85 & $(-1,0)$ & $3.4 \%{ }^{* * *}$ \\
\hline Desai and Jain (1999) & United States & $1975-1991$ & 144 & $(-1,1)$ & $3.84 \%^{* * *}$ \\
\hline Krishnaswami and Subramaniam (1999) & United States & $1978-1993$ & 118 & $(-1,1)$ & $3.28 \%{ }^{* * *}$ \\
\hline Mulherin and Boone (2000) & United States & $1990-1999$ & 106 & $(-1,1)$ & $4.51 \%^{* * *}$ \\
\hline Maxwell and Rao (2003) & United States & $1976-1997$ & 79 & $(0,1)$ & $3.59 \%{ }^{* * *}$ \\
\hline Veld and Veld-Merkoulova (2008) & United States & $1995-2002$ & 91 & $(-1,1)$ & $3.07 \%^{* * *}$ \\
\hline Kirchmaier (2003) & Western Europe & $1989-1999$ & 48 & $(-1,1)$ & $5.4 \%^{* * *}$ \\
\hline Veld and Veld-Merkoulova (2004) & Western Europe & $1987-2000$ & 156 & $(-1,1)$ & $2.62 \%{ }^{* * *}$ \\
\hline Sudarsanam and Qian (2007) & Western Europe & $1987-2005$ & 157 & $(-1,1)$ & $4.82 \%{ }^{* * *}$ \\
\hline Murray (2000) & United Kingdom & $1992-1998$ & 25 & $(-1,1)$ & $-0.19 \%$ \\
\hline Schauten, Steenbeek, and Wycisk (2001) & United Kingdom & $1989-1996$ & 23 & $(-1,1)$ & $2.13 \%^{\text {n..r. }}$ \\
\hline Sin and Ariff (2006) & Malaysia & $1986-2002$ & 85 & $(-1,0)$ & $1.80 \%{ }^{*}$ \\
\hline
\end{tabular}


Notes to Table 1: This table presents the cumulative average abnormal stock returns around the announcement dates of spin-offs. ${ }^{\text {n.r. }}=$

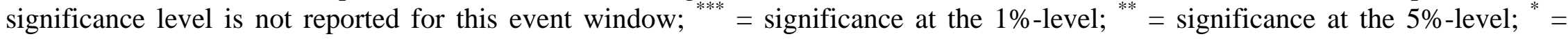
significance at the $10 \%$-level. 
Table 2: Mean and median abnormal returns around spin-off announcements

\begin{tabular}{|l|l|}
\hline Mean & $\begin{array}{l}3.02 \%^{* * *} \\
(13.23)\end{array}$ \\
\hline Standard deviation & 1.90 \\
\hline Median & $\begin{array}{l}2.90^{* * *} \\
(6.84)\end{array}$ \\
\hline Maximum & $7.80 \%$ \\
\hline Minimum & $-5.29 \%$ \\
\hline $\begin{array}{l}\text { Number of positive } \\
\text { observations }\end{array}$ & 67 \\
\hline $\begin{array}{l}\text { Total number of } \\
\text { observations }\end{array}$ & 69 \\
\hline
\end{tabular}

Notes to Table 2: This table contains the abnormal return statistics of the 69 observations for the 26 studies. Test-statistics are in parentheses. The significance of the means is tested using a $t$-statistic. The significance of the medians is tested using the Wilcoxon signed rank test; ${ }^{* * *}=$ significance at the $1 \%$-level; ${ }^{* *}=$ significance at the $5 \%$-level; ${ }^{*}=$ significance at the $10 \%$-level. 
Table 3: Meta-analysis

\begin{tabular}{|c|c|c|c|c|}
\hline Variable & Coefficient & & & \\
\hline & (1) & $(2)$ & (3) & (4) \\
\hline Intercept & $\begin{array}{l}3.47^{* * *} \\
(4.13)\end{array}$ & $\begin{array}{l}3.51^{* * *} \\
(4.14)\end{array}$ & $\begin{array}{l}3.51^{* * *} \\
(3.91)\end{array}$ & $\begin{array}{l}3.44^{* * *} \\
(6.54)\end{array}$ \\
\hline Back-to-basics & $\begin{array}{l}0.71 \\
(0.60)\end{array}$ & $\begin{array}{l}0.66 \\
(0.52)\end{array}$ & $\begin{array}{l}0.73 \\
(0.65)\end{array}$ & \\
\hline Industrial focus & $\begin{array}{l}1.34^{* * *} \\
(3.59)\end{array}$ & $\begin{array}{l}1.32^{* * *} \\
(3.67)\end{array}$ & $\begin{array}{l}1.41^{* * *} \\
(3.92)\end{array}$ & $\begin{array}{l}1.39^{* * *} \\
(3.59)\end{array}$ \\
\hline Information asymmetry & $\begin{array}{l}0.23 \\
(0.22)\end{array}$ & $\begin{array}{l}0.22 \\
(0.22)\end{array}$ & $\begin{array}{l}0.31 \\
(0.33)\end{array}$ & \\
\hline Tax advantages & $\begin{array}{l}1.02^{* * *} \\
(3.29)\end{array}$ & $\begin{array}{l}1.04^{* * *} \\
(3.33)\end{array}$ & $\begin{array}{l}1.14^{* *} \\
(2.63)\end{array}$ & $\begin{array}{l}0.79^{* * *} \\
(3.41)\end{array}$ \\
\hline Taxable spin-offs & $\begin{array}{l}-0.87^{*} \\
(-1.70)\end{array}$ & $\begin{array}{l}-0.84 \\
(-1.46)\end{array}$ & $\begin{array}{l}-0.94^{*} \\
(-1.89) \\
\end{array}$ & $\begin{array}{l}-0.87^{* *} \\
(-2.28)\end{array}$ \\
\hline Regulatory advantages & $\begin{array}{l}0.81^{* *} \\
(2.61)\end{array}$ & $\begin{array}{l}0.68 \\
(1.65)\end{array}$ & $\begin{array}{l}0.88^{* *} \\
(2.38)\end{array}$ & $\begin{array}{l}0.83^{* * *} \\
(3.52)\end{array}$ \\
\hline Size & $\begin{array}{l}2.76^{* * *} \\
(6.11)\end{array}$ & $\begin{array}{l}2.62^{* * *} \\
(4.78)\end{array}$ & $\begin{array}{l}2.88^{* * * *} \\
(5.20)\end{array}$ & $\begin{array}{l}2.63^{* * *} \\
(6.22)\end{array}$ \\
\hline Completed & $\begin{array}{l}-1.09^{*} \\
(-1.79)\end{array}$ & $\begin{array}{l}-1.15^{*} \\
(-1.81)\end{array}$ & $\begin{array}{l}-1.02 \\
(-1.59) \\
\end{array}$ & $\begin{array}{l}-1.03^{*} \\
(-1.84) \\
\end{array}$ \\
\hline United States & $\begin{array}{l}0.30 \\
(0.35)\end{array}$ & $\begin{array}{l}0.10 \\
(0.11)\end{array}$ & $\begin{array}{l}0.44 \\
(0.61)\end{array}$ & \\
\hline Early study & $\begin{array}{l}-0.52 \\
(-1.62)\end{array}$ & $\begin{array}{l}-0.42 \\
(-1.03)\end{array}$ & $\begin{array}{l}-0.62 \\
(-1.49) \\
\end{array}$ & \\
\hline Top-3 journal & & $\begin{array}{l}0.25 \\
(0.51) \\
\end{array}$ & & \\
\hline SSCI & & & $\begin{array}{l}-0.25 \\
(-0.43)\end{array}$ & \\
\hline $\mathrm{R}^{2}$ & 0.26 & 0.26 & 0.26 & 0.24 \\
\hline Adjusted $\mathrm{R}^{2}$ & 0.13 & 0.12 & 0.12 & 0.17 \\
\hline Number of observations & 69 & 69 & 69 & 69 \\
\hline
\end{tabular}


Notes to Table 3: This table contains the results of the meta-analysis based on 69 observations for the 26 studies that analyze abnormal returns. $t$-statistics, based on White (1980) heteroscedasticity-consistent standard errors, are in parentheses. The dependent variable is the abnormal return for event period t; Back to basics = a statement is made by management that the spin-off is announced in order to specialize or go "back-to-basics" ( 1 = Statement is made); Industrial focus = Parent company is in a different industry $(1=$ Yes); Information asymmetry $=$ Measure of information asymmetry between management of the firm and outsiders ( $1=$ High information asymmetry); Tax advantages $=$ Spin-off leads to a tax advantage $(1=$ Yes $)$; Taxable spin-offs $=$ Spin-off is taxable $(1=$ Yes $)$; Regulatory advantages $=$ Spin-off leads to a regulatory advantage $(1=$ Yes); Size $=$ Relative size of spin-off compared to total assets of the parent firm $(1=$ Large); Completed = Spin-off is completed after the announcement (1 = Yes); United States $=$ Study is on American spin-offs ( 1 = USA spin-off); Early study = Year in which study is either published, or the latest draft of the working paper ( 1 = published in 1997 or earlier); Top-3 journal = Published in one of the Top-3 finance journals, i.e. The Journal of Finance, Journal of Financial Economics or The Review of Financial Studies ( 1 = Yes); SSCI = Published in a journal that is included in the list of the Social Sciences Citations Index $(\mathrm{SSCI})$ of $2006(1=$ Yes $) ;^{* * *}=$ significance at the $1 \%$-level; $^{* *}=$ significance at the $5 \%$-level; ${ }^{*}=$ significance at the $10 \%$-level. 
Table 4: Long-run stock market performance

Panel A: Pro-forma combined firms

\begin{tabular}{|c|c|c|c|c|c|c|}
\hline \multirow[t]{2}{*}{ Study } & \multirow{2}{*}{$\begin{array}{l}\text { Research } \\
\text { period }\end{array}$} & \multirow[t]{2}{*}{ Observations } & \multicolumn{4}{|c|}{ Event window } \\
\hline & & & $\begin{array}{l}\mathrm{t}_{\mathrm{sp}}+6 \\
\text { months }\end{array}$ & $\begin{array}{l}\mathrm{t}_{\mathrm{sp}}+12 \\
\text { months }\end{array}$ & $\begin{array}{l}\mathrm{t}_{\mathrm{sp}}+24 \\
\text { months }\end{array}$ & $\begin{array}{l}\mathrm{t}_{\mathrm{sp}}+36 \\
\text { months }\end{array}$ \\
\hline $\begin{array}{l}\text { Cusatis, Miles, } \\
\text { and Woolridge } \\
\text { (1993) }\end{array}$ & $\begin{array}{l}1965- \\
1988\end{array}$ & 141 & & $4.7 \%$ & $18.9 \%^{* *}$ & $13.9 \%$ \\
\hline $\begin{array}{l}\text { Desai and Jain } \\
\text { (1999) }\end{array}$ & $\begin{array}{l}1975- \\
1991\end{array}$ & 155 & & $7.7 \%$ & $12.7 \%$ & $19.8 \%^{* * *}$ \\
\hline $\begin{array}{l}\text { Veld and Veld- } \\
\text { Merkoulova } \\
\text { (2004) }\end{array}$ & $\begin{array}{l}1987- \\
2000\end{array}$ & $45-61^{\mathrm{a}}$ & $-2.2 \%$ & $-2.3 \%$ & $4.2 \%$ & $2.0 \%$ \\
\hline $\begin{array}{l}\text { Sudarsanam and } \\
\text { Qian (2007) }\end{array}$ & $\begin{array}{l}1987- \\
2002\end{array}$ & 129 & & $-2.3 \%$ & $8.3 \%$ & $8.4 \%$ \\
\hline
\end{tabular}

Panel B: Parent firms

\begin{tabular}{|c|c|c|c|c|c|c|}
\hline \multirow[t]{2}{*}{ Study } & \multirow{2}{*}{$\begin{array}{l}\text { Research } \\
\text { period }\end{array}$} & \multirow[t]{2}{*}{ Observations } & \multicolumn{4}{|c|}{ Event window } \\
\hline & & & $\begin{array}{l}\mathrm{t}_{\mathrm{sp}}+6 \\
\text { months }\end{array}$ & $\begin{array}{l}\mathrm{t}_{\mathrm{sp}}+12 \\
\text { months }\end{array}$ & $\begin{array}{l}\mathrm{t}_{\mathrm{sp}}+24 \\
\text { months }\end{array}$ & $\begin{array}{l}\mathrm{t}_{\mathrm{sp}}+36 \\
\text { months }\end{array}$ \\
\hline $\begin{array}{l}\text { Cusatis, Miles, } \\
\text { and Woolridge } \\
\text { (1993) }\end{array}$ & $\begin{array}{l}1965- \\
1988\end{array}$ & 131 & $6.8 \%{ }^{*}$ & $12.5 \%{ }^{* *}$ & $26.7 \%^{* * *}$ & $18.1 \%$ \\
\hline $\begin{array}{l}\text { McConnell, } \\
\text { Ozbilgin, and } \\
\text { Wahal (2001) }\end{array}$ & $\begin{array}{l}1989- \\
1995\end{array}$ & 80 & $8.6 \%$ & $13.5 \%$ & $19.2 \%$ & $5.1 \%$ \\
\hline $\begin{array}{l}\text { Desai and Jain } \\
\text { (1999) }\end{array}$ & $\begin{array}{l}1975- \\
1991\end{array}$ & 155 & & $6.5 \%$ & $10.6 \%$ & $15.2 \%$ \\
\hline $\begin{array}{l}\text { Veld and Veld- } \\
\text { Merkoulova } \\
\text { (2004) }\end{array}$ & $\begin{array}{l}1987- \\
2000\end{array}$ & $68-106^{\mathrm{a}}$ & $3.9 \%$ & $-0.7 \%$ & $6.5 \%$ & $-0.4 \%$ \\
\hline $\begin{array}{l}\text { Sudarsanam and } \\
\text { Qian (2007) }\end{array}$ & $\begin{array}{l}1987- \\
2002\end{array}$ & 129 & & $-3.9 \%$ & $6.2 \%$ & $7.1 \%$ \\
\hline
\end{tabular}


Panel C: Subsidiaries

\begin{tabular}{|c|c|c|c|c|c|c|}
\hline \multirow[t]{2}{*}{ Study } & \multirow{2}{*}{$\begin{array}{l}\text { Research } \\
\text { period }\end{array}$} & \multirow[t]{2}{*}{ Observations } & \multicolumn{4}{|c|}{ Event window } \\
\hline & & & $\begin{array}{l}\mathrm{t}_{\mathrm{sp}}+6 \\
\text { months }\end{array}$ & $\begin{array}{l}\mathrm{t}_{\mathrm{sp}}+12 \\
\text { months }\end{array}$ & $\begin{array}{l}\mathrm{t}_{\mathrm{sp}}+24 \\
\text { months }\end{array}$ & $\begin{array}{l}\mathrm{t}_{\mathrm{sp}}+36 \\
\text { months }\end{array}$ \\
\hline $\begin{array}{l}\text { Cusatis, Miles, } \\
\text { and Woolridge } \\
\text { (1993) }\end{array}$ & $\begin{array}{l}1965- \\
1988\end{array}$ & 146 & $-1.0 \%$ & $4.5 \%$ & $25.5 \%{ }^{* *}$ & $33.6 \%{ }^{* *}$ \\
\hline $\begin{array}{l}\text { McConnell, } \\
\text { Ozbilgin, and } \\
\text { Wahal (2001) }\end{array}$ & $\begin{array}{l}1989- \\
1995\end{array}$ & 96 & $8.9 \%$ & $7.2 \%$ & $5.8 \%$ & $-20.9 \%$ \\
\hline $\begin{array}{l}\text { Desai and Jain } \\
\text { (1999) }\end{array}$ & $\begin{array}{l}1975- \\
1991\end{array}$ & 162 & & $15.7 \%^{* * *}$ & $36.2 \%^{* * *}$ & $32.3 \%^{* * *}$ \\
\hline $\begin{array}{l}\text { Veld and Veld- } \\
\text { Merkoulova } \\
\text { (2004) }\end{array}$ & $\begin{array}{l}1987- \\
2000\end{array}$ & $53-70^{\mathrm{a}}$ & $12.0 \%$ & $12.6 \%$ & $13.7 \%$ & $15.2 \%$ \\
\hline $\begin{array}{l}\text { Sudarsanam } \\
\text { and Qian } \\
(2007)\end{array}$ & $\begin{array}{l}1987- \\
2002\end{array}$ & 142 & & $7.2 \%$ & $17.5 \%$ & $23.0 \%{ }^{*}$ \\
\hline
\end{tabular}

Notes to Table 4: This table presents the results on the long-run stock performance of parents, subsidiaries and pro-forma combined firms involved in spin-offs. The long-run performance is measured as the buy-and-hold abnormal return after the spin-off completion. $\mathrm{t}_{\mathrm{sp}}$ represents the spin-off completion date. ${ }^{* * *}=$ significance at the $1 \%$-level; ${ }^{* *}=$ significance at the $5 \%$-level; ${ }^{*}=$ significance at the $10 \%$-level.

${ }^{a}=$ the number of observations is different for different event windows (pro-forma combined firms: 6, 12, 24, respectively 36 months: 61, 61, 51, respectively 45 observations; parents: 6, 12, 24, respectively 36 months: 106, 105, 86, respectively 68 observations; subsidiaries: $6,12,24$, respectively 36 months: 70, 70, 60, respectively 53 observations. 